\title{
SOME HISTORICAL ASPECTS OF LEPROSY IN CEYLON DURING THE DUTCH PERIOD 1658-1796
}

by

\author{
C. DE. F. W. GOONARATNA
}

IN 1594 nine North Netherland merchants formed a 'Company of Far Lands' for the express purpose of establishing Dutch trade in the East. Two pioneer expeditions in 1597 and 1598 proved to be financially so successful that in spite of disastrous losses of men and ships by today's standards, numerous commercial companies mushroomed in Amsterdam to exploit the riches of trade in the Far East. However, it was soon realized that competition between these companies led to higher purchase prices in the East and lower sale prices in Europe. So, after a series of lengthy and complicated negotiations, these companies amalgamated, largely due to the efforts of the leading Dutch statesman Johan van Oldenbarnevelt. ${ }^{1}$ Thus the Dutch East India Company or VOC (Vereenigde Oost-Indische Compagnie) came into being on 20 March 1602. The VOC had the blessings of Prince Maurice, and its governing body of Seventeen Directors (Hereen XVII) was empowered by the States General to 'wage defensive war, build fortresses and strongholds in the East and to conclude treaties of peace and alliance'. It was predicted even at that time, that the VOC would hardly confine itself to friendly barter. In fact, until it was formally dissolved on the last day of the year 1799, the history of the VOC is one of ruthless war and conquest on both land and sea. This tiny Dutch nation had, at one stage, complete control of the seas and the trade in Europe, the Mediterranean, the West Indies and the East.

When the VOC first turned its attention towards Ceylon, the Portuguese had control of the western coastal areas of the island and the Jaffna Peninsula ${ }^{2}$ in the north. However, King Rajasingha II still ruled over the central Kandyan areas ${ }^{3}$ of Ceylon, when on behalf of the VOC, van Diemen concluded a treaty in 1637 with King Rajasingha of Kandy to expel the Portuguese from the island. Although Dutch hostilities against the Portuguese were commenced in 1638 as a direct consequence of

1 Johan van Oldenbarnevelt played a leading role in the formation of the VOC (1602) and the conclusion of a twelve-year treaty between Spain and the Netherlands (1609), the latter much against the wishes of Prince Maurice, a powerful section of Amsterdam merchants and a Calvinist extremist group. Before the truce expired in 1621, Oldenbarnevelt was tried on a trumped-up charge of high treason, and duly executed. His demise and the expiry of the truce in 1621, gave the VOC much greater scope for offensive action.

(The Dutch abbreviation VOC actually stands for the United Netherlands Chartered East India Company).

2 The Jaffna Peninsula is in the northern part of Ceylon. It came under the Jaffina Commandery, and its capital city was Jaffna. For administrative purposes the areas under Dutch control were divided into the Jaffna Commandery, Colombo Commandery and the Galle Commandery.

The eastern parts of the Island came under Dutch rule after 1766 (see fig. 1).

Kandy, the capital of the central kingdom of Rajasingha II. Wreathed by the beauty of surrounding hills and steeped in thistory, Kandy is today the capital of the Central Province of Ceylon, and a popular tourist resort"(see fig. 1). 
this treaty, it was not until 1654 that this campaign was really intensified. At last in 1658, after much bloody fighting, the Dutch vanquished the Portuguese and took control of the western coastal areas and the Jaffna Peninsula. They held these areas until 16 February 1796 when Ceylon fell into British hands. Ceylon was made a Crown Colony in 1802, and remained so until 4 February 1948, when she became a fully independent nation within the British Commonwealth.

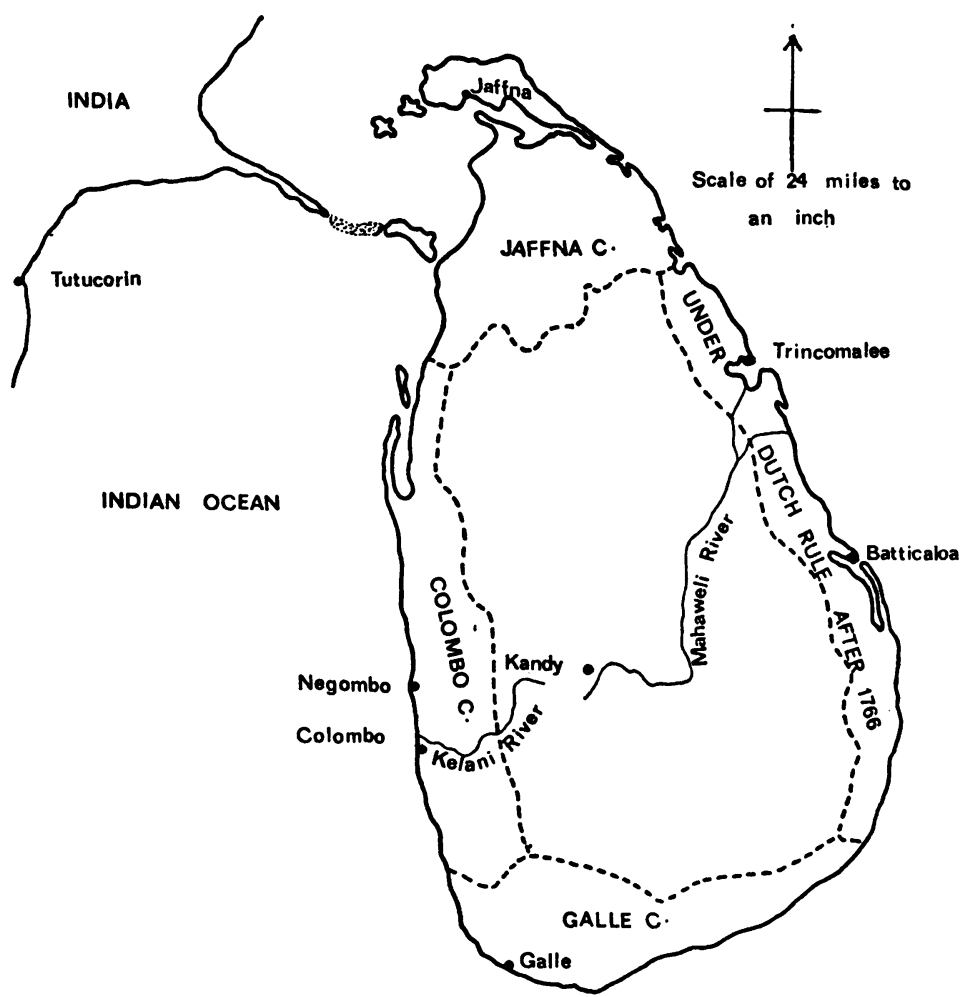

Figure 1

Map of Ceylon showing areas ruled by the Dutch. Only a few important towns and two of the several rivers in the island are depicted. The letter C. after Colombo, Jaffna and Galle stands for Commandery. (After G. C. Mendis 1963).

Administrative control of the island during the Dutch period was in the hands of Dutch Governors who were responsible to the Supreme Indian Government at Batavia.4 A Political Council consisting of Dutch appointees advised the Governor on matters pertaining to administrative control of the island and kept him informed of important local developments. Important resolutions of the Dutch Political Council were communicated to the Supreme Government at Batavia, and instructions from the latter were discussed in the Political Council. It is on the existing records of the Resolutions of the Dutch Political Council in Ceylon that much of my information is based.

Other sources of information include the memoirs, diaries and instructions left by

4 Batavia. On 30 May 1619 Jan Pieterszoon Coen forcibly seized the Javanese port of Jakatrajust one more example of 'offensive action' taken by the VOC. The fortified town of Batavia was built on the ruins of Jakatra. Most of the Eastern and Far Eastern affairs of the VOC were directly controlled from Batavia. 


\section{De. F. W. Goonaratna}

Dutch Governors of the island to their successors in office, and placcaats issued by them from time to time about the disease. These and other Dutch records show that leprosy was prevalent among the European as well as the native population during this period. They contain remarkably accurate descriptions of the signs and symptoms of leprosy, and the methods employed by them to prevent its spread. That leprosy was both a source of fear and an administrative problem to the Dutch rulers of the island is also indubitable.

The years of Dutch rule over the island will always be remembered by association with the Roman-Dutch Law, Thesawalamai, introduction of printing to Ceylon, and construction of the Leper Asylum at Hendala, a few miles north of Colombo ${ }^{5}$ near the mouth of the Kelani river ${ }^{6}$ (fig. 1).

The Dutch were great jurists, and the Roman-Dutch Law, which is Roman law adapted by the Dutch to suit their own requirements, is to this day the basis for the common law of Ceylon. On the instructions of Governor Cornelius Joan Simons (1703-1707), who was a graduate in laws of a Dutch University, the then Dissawe of Jaffna, ${ }^{7}$ Claasz Isaaks compiled and codified the Thesawalamai, which is still observed as the law in matters such as inheritance and mortgage by the Tamils. ${ }^{8}$ The Dutch also introduced printing to Ceylon. The first printing press was set up in 1736 , and portions of the Bible and various religious works were printed both in Sinhala and Tamil. ${ }^{8 a}$ Another noteworthy initiative taken by the Dutch administration was the setting-up of the Leper Asylum at Hendala. It was completed in 1708, and still exists today as the Government Leprosy Hospital, Hendala. The events that led to the construction of the Leper Asylum at Hendala are in themselves interesting.

Probably the earliest authentic reference to leprosy in Ceylon is to be found in the Resolutions of the Dutch Political Council in Ceylon dated 10 March 1685. An extract reads as follows:

His Excellency the Governor mentioned that the Chief Surgeon of this Castle had on several occasions submitted to him that there were already in the Hospital several persons afflicted with the dread disease of leprosy, and that this awful disease had already begun to spread among the children of native women who had European husbands and that a number of such people who are so afflicted came daily to the houses to beg, and that the servants of these inhabitants too bring articles of one sort or another for sale on the streets, and to the houses, and that it is thereby natural that this dreadful canker will increase and infect people of our nation too.

I consider significant the observation of the 'Chief Surgeon' that the disease had begun to 'spread among children'. If indeed the Chief Surgeon had recognized that infection of children showed that the disease was spreading fast, it is an extremely shrewd observation, because spread of the disease among children is recognized today as one of the hallmarks of its poor control.

The significance of the words ' . . the children of native women who had European husbands' will also bear examination. The term 'European' must refer to the Portu-

s Colombo (see fig. 1) is the capital of Ceylon today. It came within the Colombo Commandery of the Dutch Period.

- Kelani River, the second longest river in Ceylon, the longest being the Mahaweli (see fig. 1). The mouth of the Kelani is a few miles north of the modern Colombo Harbour.

${ }^{7}$ Dissawe. Each Commandery was under the control of a Dutch administrative officer who was designated a Dissawe.

${ }_{8}$ and ${ }^{8 a}$ The two major communities in Ceylon today, as it was in the Dutch Period, are the Sinhalese and the Tamils. The mother-tongue of the Sinhalese is Sinhala, and that of the Tamil people, Tamil. 


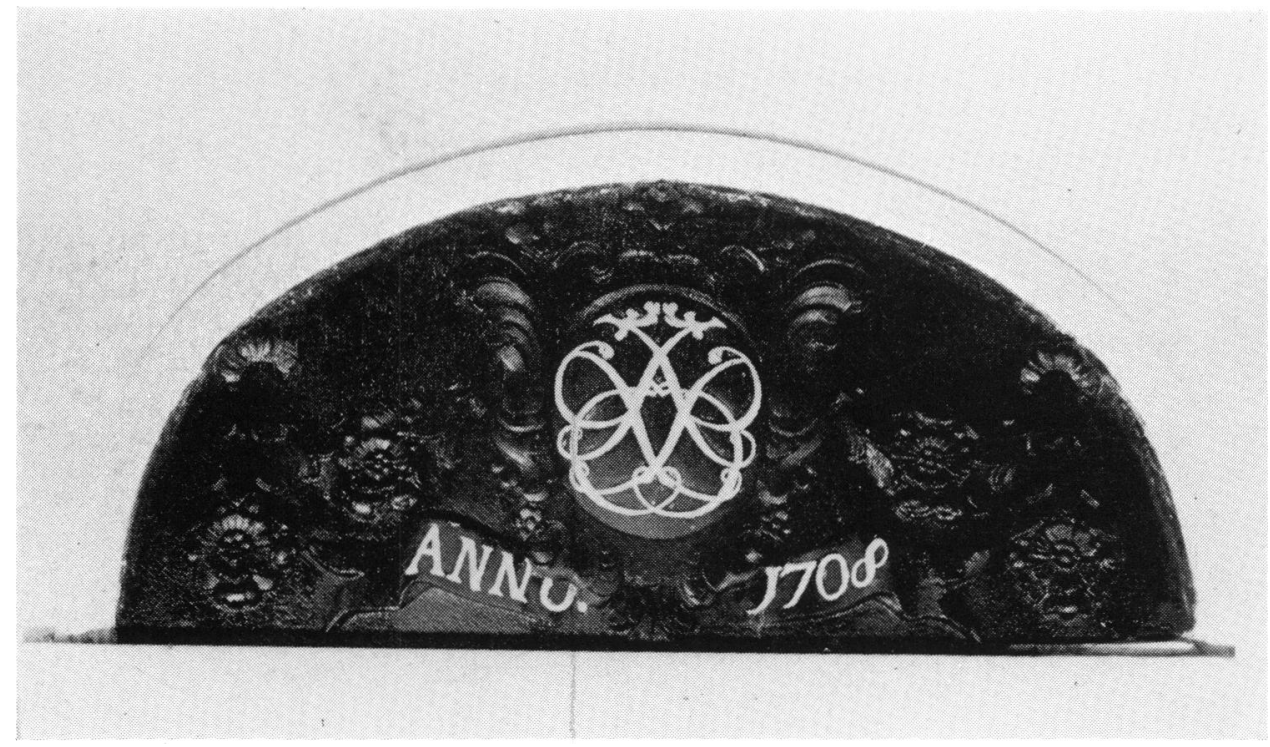

Figure 2

The stone inscription bearing the monogram of Governor Hendrick Becker. This stone inscription may be seen at the entrance to the administration building of the Government Leprosy Hospital, Hendala. 


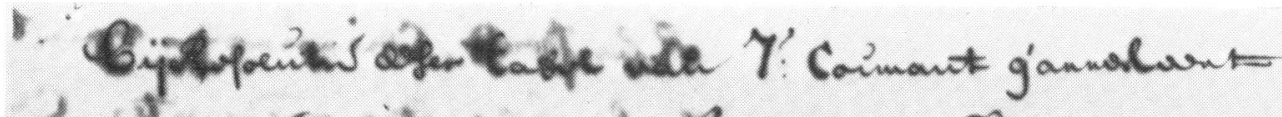

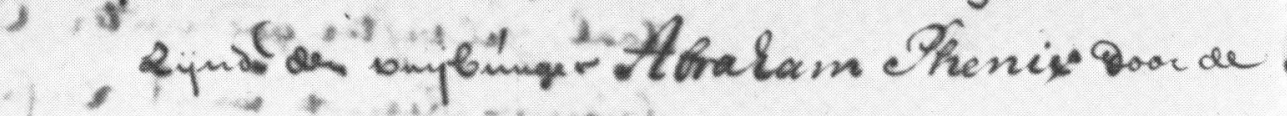

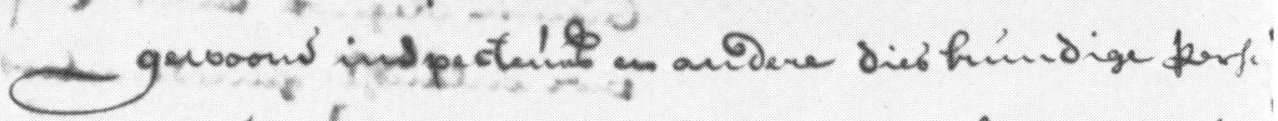

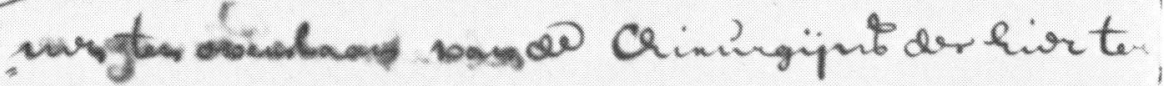

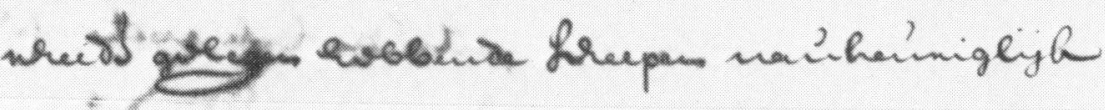

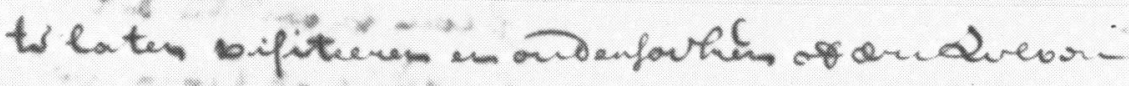

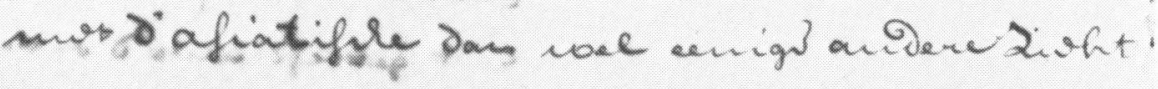

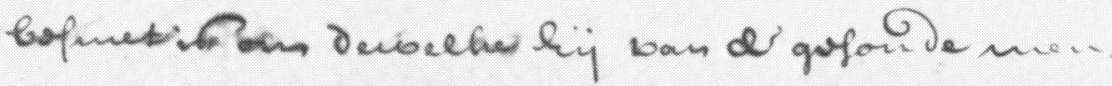

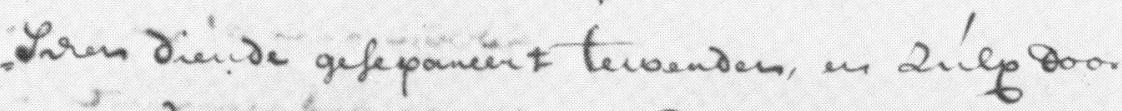

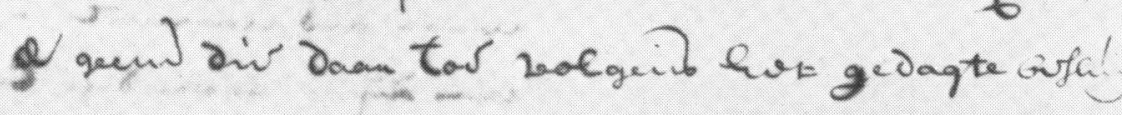 ODoor Den reere Coumniffanib gecommittent

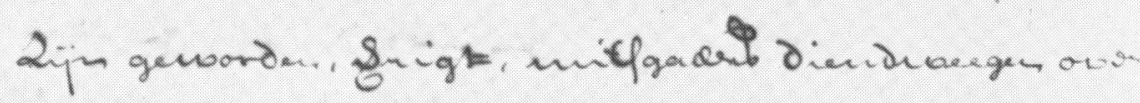 gegewan uofende dit ondenvolge be Kappount bijroiff wan sheaning}

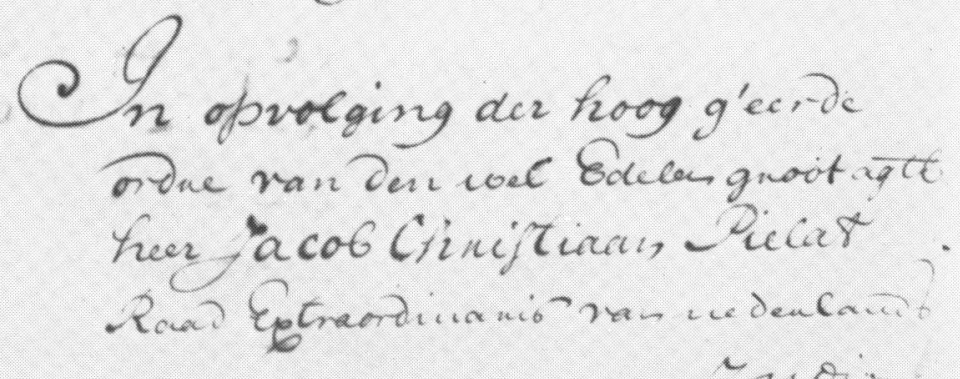

Figure 3

On 22 October 1733 the Special Commissioners' report on Abraham Phenix was tabled at a meeting of the Dutch Political Council in Ceylon. His name appears on the second line. The first lines of the report itself appear in the last paragraph, where the name of Jacob Christian Pielat, who was the Governor at the time may be made out. (Ceylon National Archives, G.A. 1/69, dated 22 October 1733). 
guese or to the Dutch. In this context it certainly refers to the Portuguese, and not to the Dutch, because soon after the reference to the 'European husbands' one comes across the phrase 'and infect people of our nation too'. A distinction is clearly made between 'European husbands' and 'people of our nation', the latter referring of course, to the Dutch people. I think it is clear, therefore, that the words 'European husbands' really refer to Portuguese husbands. By further examination of records of the Dutch Period I intend to show that the criteria employed by the Dutch Surgeons of that time to diagnose leprosy are remarkably accurate. Fears are expressed in this extract dated 10 March 1685 that the disease might infect 'people of our [Dutch] nation too'. From the foregoing one may reasonably conclude that leprosy had not been detected among Dutch inhabitants of Ceylon up to that time.

Other references to leprosy prior to the commencement of work on the Leper Asylum are to be found in the minutes of the Dutch Political Council. For instance, noting the increasing prevalence of the disease, this Council resolved on 20 September 1691: ' $\ldots$ that Special Commissioners be appointed to make a survey, accompanied by the Chief Surgeon, to ascertain how many persons are afflicted with [leprosy], in order that steps may be taken to consider ... . how best to overcome this ... and where these persons [who are afflicted] could most suitably be billetted outside the city ... $\therefore$ To assist the Chief Surgeon in these matters, two members of the Council, Captain Dominique de Chavonnes and Merchant Pieter Coessart were appointed as Commissioners.

The resolutions of the Council dated 26 October 1693 also reveal the increasing anxiety of the Dutch authorities about the spread of 'the dread disease of Leprosy'. Further, on this date the Council decided, on the suggestion of the Governor, to ask Their Excellencies of the Supreme Indian Government at Batavia authority to construct an asylum at a suitable site. As measures calculated to prevent the spread of the disease the Council resolved first to segregate those suffering from leprosy in a suitable asylum. Second, they speculated 'whether steps should not also be taken to prohibit anyone who is smitten with the disease from being on the public highways or in public company, and much less to walk along the streets selling any native cooked food such as "pittoos" and "apes"," or sit in the bazaar with the same ... upon the penalty that those who are found to contravene this order shall be arrested forthwith, banished to Tutucorin ${ }^{10}$ and not be allowed to return'.

These tentative suggestions raised in the Council were swiftly put into action. The minutes of the Political Council meeting dated 3 November 1693 show that the Council thought it necessary to take a census of those suffering from leprosy to persuade 'Their Excellencies of the Supreme Indian Government at Batavia' about the urgent need for an asylum. In order to inform 'Their Excellencies ... of the number of persons who have been afflicted by the Lord God with the disease of leprosy ...', examination of the population was to be conducted by the Chief Surgeon of the Castle, Pieter de Hooy, the Chief Surgeon of the City, Mighiel Francis, and Surgeon Jan Pietersz, in the presence of two Special Commissioners, namely Merchant

- 'Pittoos' and 'apes'. These are preparations of food made mainly out of rice or wheat flour and coconut milk. These names are in use, and the preparations commonly consumed in Ceylon even today.

${ }_{10}$ Tutucorin. A VOC outpost at the southern tip of South India (see fig. 1). 


\section{De. F. W. Goonaratna}

Gisbert Ferreris and Lieut. Joan Jacob Weiknauw. The Governor of that time issued a placcaat, most of the relevant sections of which are set out below-

Thomas van Rhee Commissioner Extraordinary of India, Governor and Director of the Island of Ceylon, the Coast of Madura ..., and his Council.

Hereby notify, with greetings, all those who shall see this or hear it read. How we have, to our regret observed that the awful disease of leprosy has begun to increase from year to year ... We have ... been persuaded to devise plans for preventing the same with the blessings of God Almighty in the most fitting manner. [We have] finally decided to appoint expert Surgeons, accompanied by two Commissioners from this Council and the Honourable Court of Justice ... for the purpose of visiting and examining all families, both European as well as native, Christians, heathens, Moors, male and female slaves, no one excepted, in order to ascertain which of them are afflicted with ... . leprosy and to note [their] names.

For this purpose, the said Commissioners and Surgeons will commence their inspection from Monday next the 9th instant, wherefore we make no delay in . . . expressly ordering and commanding each and every person not only to remain in their houses when the Commissioners visit them, but also to present their families, their children, male and female slaves, and all others residing with them for examination, without suppressing or concealing or withholding any of them ... upon the penalty that anyone who at the time of the visit to their homes is found to be absent or suppresses, conceals or withholds any member of their household be they friends, companions, children, male or female slaves, or whoever else it may be shall be punished arbitrarily according to the circumstances of the case.

We ... have resolved and decided to order and command each and every person who finds that he is smitten with leprosy, be he European, native, child, slave or whoever it be, no one excepted, after the publication of this notification to keep themselves away from the public streets and from all public company or other gatherings, and to refrain from selling any articles of food along the streets or in the bazaar upon the penalty that those who are apprehended in the same shall, without any regard to any plea or excuse or any respect of person, be banished to Tutucorin and shall not be permitted to return here again. ...

Here, I wish to draw attention to two matters. First, it will be evident from the words 'afflicted by the Lord God with the disease of leprosy' that the immediate cause of leprosy was thought to be a visitation of Divine Wrath. This attitude however was by no means unique to the Dutch. In fact, until the identification of Mycobacterium leprae by Hansen in the 1870 s cast serious doubts upon it, this attitude prevailed in England, Europe and in all regions of the world where leprosy was found and where the Christian teaching prevailed. W. H. Jopling (1965) the Consultant Leprologist at the London Hospital for Tropical Medicine observes that: 'Of the many and varied emotions aroused by leprosy throughout the centuries, fear and revulsion have predominated. Doubtless the Old Testament with its use of the word "leprosy" as a punishment for sin, has played an important part in influencing social reaction to the actual disease wherever Christianity has prevailed, particularly in Europe during and after the Middle Ages'.

This sort of attitude towards the disease gave proprietary rights over leprosy patients to churches, Christian missions and other religious institutions where they existed. However, it had amusing results sometimes. The medical historian Sir William MacArthur (1953) records the frequent misdiagnosis of other skin disorders as leprosy in medieval English 'leper houses', in the following words:

When we come to the subject of leper houses, we find the same misunderstanding and exaggeration. During the 1100 s there was a great outburst of sympathy and pity for the lepers encouraged by clerical influence. .... In their zeal . . . ladies in a kind of religious fervour, would wash the feet of lepers and embrace their diseased bodies. It is some consolation to us to reflect that in many instances these devotees ran no greater risk than that of contracting scabies. 


\section{Some Historical Aspects of Leprosy in Ceylon, 1658-1796}

The second point I wish to comment on is that the force of the language of this placcaat dated 3 November 1693 is matched by the swiftness of the action proposed in it. Clearly, anxiety about the spread of leprosy was reaching proportions close to panic. We have to judge the subsequent somewhat hasty actions of Governor C. J. Simons against this background.

But allow me to digress for a moment here, to acquaint you with the misfortunes of a Dutch Surgeon by the name of Jan Siebertsz, and five slaves belonging to one Simon Cat, all of whom contracted leprosy. It appears that in 1694, Siebertsz contracted leprosy and volunteered this information to the Political Council. He also asked that he be sent with his family to Tutucorin in order that he may earn his living there by practising outside the premises of the 'Honorable Company'. After great deliberation the Council rejected this request for the curious reason that his banishment to Tutucorin 'could cause some vexation in respect of the native inhabitants'. So Surgeon Siebertsz was left to languish 'outside the City or at Mutwal'11 and draw a small monthly salary for his maintenance.

The resolutions of the Political Council dated 25 July 1704 reveal that 'Weesmeesters' (Wardens of the Orphan House) presented a petition to Governor Simons that as executors of the estate left by one Predikant Simon Cat ${ }^{12}$ they had to go through all his effects. In the course of their duties they discovered that five of his slaves, three of them male and two female, were found to be suffering from leprosy. Chief Surgeon Pieter de Hooy had examined these slaves, and his report too was tabled at this meeting. On the basis of this petition and the report of the Chief Surgeon, the Council resolved to authorize the Weesmeesters to 'keep the afflicted slaves away from public auction and write them off as unserviceable, unsaleable and condemned items'. The slaves were to be maintained at the expense of the estate of Simon Cat until the proposed asylum was completed, and a sum of money sufficient to maintain them in the asylum be set apart from his estate.

During the meeting of the Council held on 20 July 1703 the Governor revealed that authority had been given and a reasonable supply of funds made available by the Supreme Indian Government at Batavia for the construction of a Leper Asylum. Councillors van Toll, Toorzee, Valck, Sterreman and Stafforts were commissioned to look out for a suitable site for such an asylum and report to His Excellency. But as late as 10 January 1705 work on the Leper Asylum had apparently not commenced. The resolutions of the Political Council meeting held on this date show that a site at Negombo (twenty miles north of Colombo) had been chosen for an asylum. However, the Councillors conveyed to the Governor that the inhabitants of Negombo, especially the fishermen, had expressed their dissatisfaction over this choice of site. The fishermen feared that the site chosen 'so closely corresponded to the lagoon where they are mostly occupied in the fishing business, that they would therefore have to give up their trade'. Accordingly, the Council empowered its Honourable members Bloemert, Toorzee and da Costa to select a more suitable site.

The exact date on which work on the Leper Asylum at Hendala was started is not

11 Mutwal is situated at the northern part of the city of Colombo.

12 Predikant Simon Cat. The term Predikant was used for a qualified preacher. Predikants were employed by the VOC at a monthly pay of about thirty rixdollars. 


\section{De. F. W. Goonaratna}

known. However, it appears that Governor C. J. Simons had been misled by the Chief Surgeon of the Vessels regarding the status of the disease in the island. This, along with increasing anxiety about the spread of the disease, probably induced Governor Simons to commence work on a building which was far too large for the intended purpose. For, in his memoirs Governor Simons makes the following observations regarding the Leper Asylum:

The Leper Asylum on which already twice the amount granted by Their Excellencies has been spent, has given me a great deal of worry; the more so because owing to my illness I was not able to inspect the place myself, although I did so just before I was taken ill. The present condition of the unfortunate patients is described in the report of the Commissioners, who were assisted by the Chief Surgeon of the Vessels lying in the harbour. It appears that our late Chief Surgeon had somewhat exaggerated the state of affairs. I hope this is true, especially for the sake of those who were summarily dismissed on this hasty report.

The construction of the Leper Asylum at Hendala, though it was undertaken during the time of Governor Simons, was completed only during the time of his successor in office, Hendrick Becker (1707-1716). A stone inscription dated 1708 which may be seen at the Leprosy Hospital Hendala to this day (fig. 2) bears the monogram of Governor Becker. Becker has the following comments to make regarding the Leper Asylum in his Memoirs and Instructions to Isaac Augustyn Rumpe, his successor.

The Leper Asylum, commenced by his Excellency, Cornelius Joan Simons, but completed by me, is a very large building, and about eight times the size required. Their Excellencies of the Supreme Government have been justly displeased regarding this matter and because this expenditure for its upkeep amounted yearly to a considerable sum, I proposed to Their Excellencies to break down part of it and sell the materials. Authority having been received this has been done, and the asylum now has an yearly surplus. ... With a view to its affairs being properly managed, I have appointed the Merchant and Negotie Boekhouder Jacob Bouer, ${ }^{13}$ besides the Head Physician of the Dutch Hospital, and Dr. Van der Stadt, as regents, and have provided them with instructions, which are preserved at the Secretariat.

I shall now try to show that the criteria employed by the Dutch Surgeons of that period to diagnose leprosy and their descriptions of the signs and symptoms of the disease are remarkably accurate.

From the resolutions of the Dutch Political Council meeting dated 7 October 1733 it is clear that 'the well-known free-burgher Abraham Phenix' was placed under civil arrest provisionally, as it was felt that he had contracted leprosy. He was also suspected of trying to flee to the hill country to escape his banishment to Tutucorin. Furthermore, it was decided to have him examined by a panel of competent persons in order to determine whether he really had leprosy. Their findings confirmed that poor Abraham Phenix did have leprosy, and it is interesting to read the report of the special commission that was asked to report on him.

You will observe in this report tabled at the Political Council meeting on 22 October 1733 , that five ships' surgeons who while declaring that they had no experience of leprosy, nevertheless proceeded to tender the unconvincing opinion that Abraham Phenix had merely a 'morbid and scurvy-diseased physical condition', and not leprosy.

13 Negotie Boekhouder Jacob Bouer. The term 'Negotie Boekhouder' refers to a trade accountant or book-keeper. Book-keepers employed by the VOC were paid a monthly salary of six to eight rixdollars. 
However, the signs and symptoms as described by the six surgeons who thought that he had leprosy (one of whom was the warden of the Leper Asylum) should leave the reader in no doubt about the correct nature of his disease. The relevant extracts from the resolutions of the Council are translated below (see figure 3):

In compliance with the esteemed order of the Right Hon. High and Mighty Mr. Jacob Christian Pielat, Commissioner Extraordinary of the Netherlands Indies on behalf of Their Mightinesses the Supreme Indian Government over the affairs of the Island of Ceylon;

We, the undersigned, Godlof Johan Everhard van Exter [Chief Surgeon of the Dutch Hospital], Angelo Van Geyzel [Apothecary], Jacob William Becker [Chief Surgeon of the City], Jan Dents [Second Surgeon of the Dutch Hospital], Everhard Runsdorff [Surgeon of the Slave Hospital], Silvester Goedwater [Surgeon and Warden of the Leper Asylum], together with four native physicians, examined the person named Abraham Phenix, free-burgher, conscientiously and according to the best of our ability, and we found that he is smitten with the Asiatic disease or leprosy, proof of which, according to the experience gained by us of this terrible disease in these parts appeared in the following signs (or symptoms): namely, the whole body was robbed of its lively colour by a number of yellowish patches, the intervening parts had a dark shady tint which was uneven in some places, the face was swollen and had a somewhat reddish appearance, the eye-brows were somewhat swollen and had some peculiar little pale hairs, the eyes were round and drawn-in, the ears, especially the borders, and the lips of the mouth were abnormally enlarged and thick, the nose slightly thick and gaping, with the edges drawn inwards and the inside slightly ulcerated and with clotted blood; the breath was short and smelly, dirty with mist as one gets near, all the muscles of the entire body were emaciated and limp, except the fingers, which were round as if inflated, the feet from a little below the calves down to the toes with a similar inflated-like swelling and with a dark tinge of colour, weak in gait (which we tested more than once and found to be so); all of which are true signs of the type and nature of this disease; and we declare and affirm these our findings to be genuine and true, and we are prepared to support the same by solemn oath if necessary;

Further, the Chief Surgeon of the ship 'Berkenrode', Jan Van Ewijk, declared that he could not confirm that these were really the signs of leprosy. The Chief Surgeons of the ships "'t Vliegend Hart" Jan Cats and the "Proostwijk" Joseph de Croes, also declared that they have had no experience of the disease of leprosy and that in view of their inexperience they would rather leave the opinion in this case to those who were possessed of more experience and riper judgment in the matter, but that they had perceived all the above signs among those who were addicted to women and wine. On further consideration, they were inclined to agree with the opinion of the Chief Surgeon of "Paddenburgh" Jan Van Houten, who considered these signs as nothing else but a morbid and scurvy-diseased physical condition, and the Chief Surgeon of the ship "Flora" Jan Landman and the Chief Surgeons Jan Cats and Joseph Croes were of the same opinion; so that these last-mentioned five ships' surgeons sufficiently agreed in the opinion that they regarded Abraham Phenix to be in a morbid and poor physical condition, which they are prepared to support by oath if necessary.

Colombo. 13th October 1733.

[Signed]: G. J. E. van Exter, A. Van Geyzel, J. W. Becker, J. Dents, E. Runsdorff, Sr. Goedwater, Jan van Ewijk, Jan Cats, J. Van Houten, Jan Landman, and some Tamil letters [being the names of the four native physicians mentioned above].

We have here specific mention of the swelling of the face, the thickening of the eyebrow areas, nose, ears and lips which comprise the 'leonine facies' of leprosy. The surgeons observed the depigmented cutaneous patches, and the ulcerated nasal septum. There is mention of the "limp and emaciated body except the fingers, which were round as if inflated'-surely, the succulent sausage-shaped fingers indicating a neurotrophic aetiology. The same changes were observed in the toes. There is mention of muscle wasting and weakness of gait. No one who has worked in a leprosy hospital will fail to be impressed by the accuracy with which some unmistakeable features of the disease have been picked out for description. Indeed, had the Dutch surgeons but 


\section{De. F. W. Goonaratna}

mentioned thickened nerves and sensory loss, the description would have been a very complete one. Anyway, the point is that they could certainly recognize leprosy when they saw it. We have therefore to attach due significance to their diagnosis of the disease.

Nor can it be argued that, during this period, the occurrence of leprosy among Dutch people was quietly concealed. The placcaats warning persons of all origins, the several references made in the Political Council minutes to Dutchmen who had contracted the disease, such as Abraham Phenix and Surgeon Sierbertsz, admit of no such possibility.

The fact that Dutch surgeons recognized and accurately described the features of leprosy, when taken in conjunction with the fact that no attempt was made to conceal the occurrence of the disease among Dutch inhabitants, and the comments made in connection with the Political Council resolutions of 10 March 1685, leads inevitably to one conclusion. That is, that leprosy was not prevalent among the Dutch inhabitants of the island until in 1694 Surgeon Siebertsz was found to have the disease.

After the year 1733 the Resolutions of the Dutch Political Council do not reveal much in the way of interesting information regarding leprosy except that, from time to time the accounts and other fiscal matters of the Leper Asylum are tabled, and one reference is made to a curious 'lizard treatment' for leprosy tried out by a surgeon named Marwal.

On 17 April 1788 a letter was read at the Political Council meeting that two persons from the Leper Asylum at Hendala, who were afflicted with leprosy, had come under the observation of one Surgeon Major Dr. Marwal. He had 'hoped to cure them with lizard treatment'. However, the patients showed no signs of improvement after ten months of 'lizard treatment', and had to be brought back to the Asylum. This apparently did not discourage Dr. Marwal from 'requesting that the expenses incurred by both him as well as the repatriated Hon. Dissawe de Cok for the upkeep of these patients' be paid to them by the Company. Although one would have liked to have more details of this positively intriguing form of treatment, unfortunately no further information is available on the subject.

The accounts of the Leper Asylum which have been tabled in the Political Council, regularly show a surplus. In fact, on 31 May 1781 , a sum of 1300 rixdollars ${ }^{14}$ was transferred to the Company's Treasury from the asylum at the usual rate of interest, which was $4 \frac{1}{2}$ per cent per annum. There is a later reference (1788) to a similar investment of 12,000 rixdollars. The revenue of the asylum appears to have been derived from allowances made by the VOC, collections made in the churches, voluntary donations and the sale of produce, e.g. coconuts.

In June 1788 the Political Council resolved to amalgamate the asylum with the diaconate of Colombo which maintained the Orphan House and other charitable works. The accounts of the diaconate and the asylum were maintained separately even though the intention was clearly to offset the deficit of the former with the surplus

\footnotetext{
14 Rixdollars. The evolution of currency used by the VOC during its years of existence is a rather complex matter. Ignoring complicated conversion rates, it may be stated that matters stood as follows after a series of monetary reforms in the Netherlands from 1656 to 1658 -

1 rixdollar (or rial) $=60$ stuivers

1 florin (or guilder) $=20$ stuivers
} 


\section{Some Historical Aspects of Leprosy in Ceylon, 1658-1796}

revenue of the latter. With the meticulous attention to detail typical of the Dutch, the rules to be observed in this amalgamation were laid down, as follows:

Having taken into consideration that the Diaconate was in urgent need of support, and that its amalgamation with the Leper Asylum will certainly be advantageous for the Diaconate without causing any imaginable detriment to the Leper Asylum as long as the capital remained unamalgamated and untouched and because it will have the same result whether the revenue is spent on the lepers or the paupers, since the aim and object of both establishments will be met, namely, the relief of suffering.

It is accordingly resolved and decided to amalgamate the Leper Asylum with the Diaconate here, and therefore, that the funds of the Leper Asylum as at the end of August this year be transferred by the Wardens [of the Leper Asylum] to the Deacons, who will thereafter be responsible for the administration of both establishments, and that the following rules be observed in this connection-

(1) That they transfer the accounts of the funds of the Leper Asylum with effect from the 1st of September this year [1788] to the books of the Diaconate, provided that a separate account is shown of the Capital thereof, and will continue to be maintained separately.

(2) That they must curtail all such items of expenditure as have been necessary when each establishment functioned as a separate unit, but which could be saved by this amalgamation, and they must also therefore discharge all such servants in cases where one single person could be employed to serve both establishments.

(3) That in respect of the other expenses and profits of the two establishments, they must regard them as common to both, and that therefore the surplus revenue of one establishment may be used to supplement the deficit of the other.

And, further, considering that it is most essential that one or more medically qualified men should participate in the administration over the lepers, and that in this place one of the Chief Physicians has therefore always been a Co-Regent of the funds of the Leper Asylum, it is resolved and decided that the Surgeon Major Knaus, who is at present a Co-Regent of the funds of the Leper Asylum continues to function in that capacity, and to appoint also as a Co-Regent the Chief Physician of the City, Frans Wolkers, and to give them a vote at the next session of the Board of Deacons, only in respect of matters pertaining to the funds and the other interests of the Leper Asylum.

On 10 October 1791, about four and a half years before Ceylon fell into British hands, the Political Council discussed the report of one Captain Nagel that several inhabitants of the Wanny, which came under the Jaffna Commandery, ${ }^{15}$ were afflicted with leprosy. The Council resolved on this date-

that the Surgeon Barend de Wolff does not seem to have been successful in his efforts to check the disease [in the Wanny] and decided in view of the great necessity for taking timely action to prevent further spread of this evil, to transfer the Second Surgeon of the Dutch Hospital here [Colombo] Dr. Van de Putte, who is a capable officer, as Chief Physician of the Wanny, and to appoint the said Dr. Wolff to the vacant post of City Physician at Jaffna.

To summarize then, leprosy was both an administrative problem and a source of fear to the Dutch who occupied Ceylon from 1658 to 1796 . To house leprosy patients they had an asylum constructed at Hendala, six miles north of Colombo. The construction of this was completed in 1708. Somewhat harsh measures were adopted to control the spread of leprosy, which included banishment to Tutucorin, compulsory segregation in the asylum and prohibition of lepers from appearing in the streets and other public places. The criteria adopted for the diagnosis of the disease by Dutch surgeons of the time were remarkably accurate.

The first mention of a Dutchman resident in Ceylon contracting leprosy is in 1694,

15 Jaffna Commandery. See fig. 1 and footnote 2. 


\section{De. F. W. Goonaratna}

when Surgeon Siebertsz was found to have the disease. In 1733 one Abraham Phenix was found to have leprosy. However it was not uncommon among the native and Portuguese population as early as 1685 .

\section{ACKNOWLEDGEMENTS}

I wish to thank Mr. S. A. W. Mottau for his help in the translation of original Dutch documents and for his advice; the Ceylon Government Archivist Mr. Harischandra de Silva and Assistant Government Archivist Mr. M. U. de Silva for providing me with a photograph for fig. 3 and for their friendly co-operation; and Professor K. N. Seneviratne for his interest and encouragement.

This work was supported in part by a grant from the University of Ceylon, Colombo.

\section{REFERENCES}

BECKER, HENDRICK (Governor and Director of Ceylon), Memoir for His Successor Isaac Augustyn Rumpfe, 1716, (Eng. trans. by Sophia Anthonisz), Colombo, H. C. Cottle, Government Printer, 1914, p. 39.

BoXer, C. R., The Dutch Seaborne Empire 1600-1800, London, Hutchinson, 1965, pp. 304-5.

Ceylon National Archives: G.A. 1/29, dated 10 March 1685 , p. 15.

G.A. 1/31, dated 20 September 1691, p. 219.

G.A. 1/33, dated 26 October 1693, p. 283.

G.A. 1/33, dated 3 November 1693, p. 293.

G.A. 1/34, dated 28 July 1694 , pp. 156-57.

G.A. $1 / 38$, dated 20 July 1703 , pp. 207-8.

G.A. 1/39, dated 25 July 1704 , pp. 249-52.

G.A. 1/40, dated 10 January 1705, pp. 21-2.

G.A. 1/68, dated 22 October 1733, pp. 229-32.

G.A. 1/201, dated 16 June 1788 , pp. 30-31.

G.A. 1/216, dated 10 October 1791, p. 66.

DE HeERE, GERRIT, (Governor of Ceylon), Diary of Occurrences during the Tour of Ceylon from Colombo to Jaffna, July 9 to September 3 1697, (Eng. trans. by Sophia Anthonisz), Colombo, H. C. Cottle, Government Printer, 1914, p. 36.

Jopling, W. H., 'Leprosy: past, present and future', J. trop. Med. Hyg., 1965, 68, 129.

MacArthur, Lt.-Gen. Sir William, 'Mediaeval "Leprosy" in the British Isles', Lepr.Rev., 1953, 24, 11.

Mendis, G. C., Ceylon To-day and Yesterday, Colombo, Associated Newspapers of Ceylon, 1963, 2nd ed., p. 60.

Simons, Cornelius Joan. (Governor and Director of Ceylon), Memoir for His Successor Hendrick Becker, 1707, (Eng. trans. by Sophia Anthonisz), Colombo, H. C. Cottle, Government Printer, 1914, p. 22.

VANDERWALL, E. H., 'The contribution of the Dutch to the making of Ceylon', Journal of the Dutch Burgher Union of Ceylon, 1932, 22, 53-7. 